\title{
How WEAK IS THE WEAKEST-LINK PRINCIPLE? ON THE MEASUREMENT OF FIRM OWNERS' CONTROL RIGHTS
}

\author{
JEREMY S. S. EDWARDS \\ ALFONS J. WEICHENRIEDER
}

CESIFO WORKING PAPER No. 1255

CATEGORY 9: INDUSTRIAL ORGANISATION

August 2004 


\title{
HOW WEAK IS THE WEAKEST-LINK PRINCIPLE? ON THE MEASUREMENT OF FIRM OWNERS' CONTROL RIGHTS
}

\begin{abstract}
The paper argues that the weakest link principle, which has been widely used as a measure of ultimate owners' control rights, has a number of serious problems. A theoretically more satisfactory method of measuring control rights, based on voting power indices, is proposed, and the different measures are compared using a sample of large listed German firms. The different measures produce very different results. But, whichever measure is used, taking account of pyramid ownership structures has little effect on the values of control and cashflow rights. The results also show that neither first-tier nor ultimate control rights measures are adequate on their own, suggesting that further work on ownership structure and pyramids is required to obtain satisfactory measures of large owners' control rights.
\end{abstract}

JEL Code: G32, G34.

Keywords: corporate governance, control rights, weakest-link principle.

Jeremy S. S. Edwards

Faculty of Economics and Politics

University of Cambridge

Sidgwick Avenue

Cambridge CB3 9DD

United Kingdom

je12@econ.cam.ac.uk
Alfons J. Weichenrieder

Goethe University Frankfurt

Mertonstr. 17

60054 Frankfurt (Main)

Germany

a.weichenrieder@em.uni-frankfurt.de

We thank Dennis Leech for allowing us to use his algorithms for computing voting power indices, and Sheilagh Ogilvie for helpful comments. 


\section{Introduction}

In most countries, the typical listed company is controlled by a single large shareholder. The key conflict of interest in corporate governance is thus between the controlling shareholder and minority shareholders, rather than between dispersed shareholders and professional managers who run the firm but have little or no ownership stake. The extent of this conflict of interest depends on the relationship between the control rights and the cash-flow rights of the controlling shareholder (Shleifer and Vishny 1997, La Porta et al. 1999, Claessens et al. 2000, 2002, Faccio et al. 2001, Faccio and Lang 2002). Other things equal, the greater the control rights of the controlling shareholder - her ability to influence the way the company is run - the greater her ability to obtain private benefits of control at minority shareholders' expense. These private benefits of control can take many forms. The controlling shareholder can, for example, use business relations between the company and other firms that she wholly owns to exploit minority shareholders. Thus transfer pricing can be used to shift profits from the company with minority shareholders to the firm wholly owned by the controlling shareholder, or the company with minority shareholders can invest in assets that are then sold or leased at favourable terms to the wholly-owned firm (Johnson et al., 2000). Alternatively, if the controlling shareholder is also a manager of the company, minority shareholders can be exploited by paying a high salary to the controlling shareholder. Evidence of private benefits of control obtained by controlling shareholders has been provided by Barclay and Holderness (1989), Bergström and Rydqvist (1990), Zingales (1994), Nenova (2003) and Dyck and Zingales (2004). However, the greater the cash-flow rights of a controlling shareholder - the fraction of the firm's profits to which she is entitled - then, other things equal, the more closely her incentives are aligned with those of the minority shareholders, and hence the lower her incentives to pursue costly policies which divert profits from minority shareholders (Jensen and Meckling, 1976). Thus the conflict of interest is likely to be more severe if the controlling shareholder's control rights substantially exceed her cash-flow rights.

The control rights of an owner of a firm refer to that owner's ability to influence the firm's operations, and the magnitude of these rights clearly depend in some way upon the owner's share of the total voting rights in the firm. But, rather 
than developing a measure of control rights that is related to voting rights, the empirical literature on control and cash-flow rights of ownership has, following La Porta et al. (1999), equated control rights with voting rights. ${ }^{1}$ This approach has some problems. One is that an owner's power to determine the outcome of a vote by all owners is not, in general, accurately reflected by that owner's voting rights, as the extensive literature on voting power indices has shown (see Felsenthal and Machover 1998). A second problem is that in many cases this approach makes it impossible to distinguish control rights from cash-flow rights. If all shares in a company have equal voting and dividend rights then, if control and voting rights are equated, the control and cash-flow rights of the first-tier owners of the company will be identical. ${ }^{2}$ To circumvent this latter problem, empirical studies of differences between control and cash-flow rights that have equated the former with voting rights have had to identify a separate measure of cash-flow rights. There are two main ways in which this can be done. First, if firms issue classes of share that differ in terms of their relative proportion of voting rights and dividend entitlement, then it is possible to obtain separate measures of control and cash-flow rights even when the former are equated to voting rights. Second, if all shares have the same voting and dividend rights but the owner of a firm exercises control via a chain of other firms - a pyramid - the owner's control and cash-flow rights will differ even when the former are equated with voting rights.

Recent empirical studies have emphasised the second of these two ways of obtaining separate measures of control and cash flow rights when the former are equated with voting rights. Faccio et al. (2001) focus on pyramiding as the source of differences between the controlling shareholder's control and cash-flow rights in their analysis of the effect of these two forms of ownership rights on dividend payout rates in Western European and East Asian companies. In their analysis of the relationship between firm value and the control and cash-flow rights of the largest shareholder in East Asian companies, Claessens et al. (2002) consider both pyramid structures and

\footnotetext{
1 "To evaluate the potential for agency problems between ultimate owners and minority shareholders, we also want to know whether the cash flow ownership rights of the controlling shareholders are substantially different from their voting rights" (La Porta et al, 1999, page 477). See also Faccio et al. (2001) and Claessens et al. (2002).

${ }^{2}$ First-tier owners are the immediate owners of a company, as distinct from ultimate owners, which are the owners revealed by investigating the ownership of the first-tier owners, the second-tier owners, and so on.
} 
shares with different voting rights as sources of differences between control and cashflow rights, but pyramiding is by far the more important, since only 43 of the 1,301 corporations in their sample issue shares with different voting rights.

But there is a difficulty with these two studies and others that have focused on pyramiding as the source of the separation between control and cash-flow rights (Claessens et al. 2000, Faccio and Lang 2001, and La Porta et al 1999). It is not obvious how to use the voting rights at each tier of a pyramid to derive a measure of the control rights of owners who exercise control in this way. All the studies mentioned have used the weakest-link principle (henceforth WLP). This principle assigns control rights to the controlling shareholder on the basis of the minimum value of voting rights across the different links of a control chain. Thus, if a controlling shareholder has 40 per cent of the voting rights in firm A, and firm A has 20 per cent of the voting rights in firm $\mathrm{B}$, according to the WLP this shareholder has control rights of 20 per cent in firm B. The cash-flow rights of this shareholder in firm B are eight per cent (40 per cent of 20 per cent). Despite its popularity in empirical studies, the WLP is largely an ad hoc measure with little theoretical underpinning, and thus has some potentially serious problems as a measure of control rights, as discussed in Section 2 below.

This paper advocates using voting power indices to relate control to voting rights. Such an approach has two major advantages. First, it can distinguish owners' control from cash-flow rights even when all shares have the same voting and dividend rights and no owner exerts control through a pyramid. Second, it permits measures of the control rights of owners who exercise control via a pyramid to be obtained that are theoretically more satisfactory than those given by the WLP. These advantages make it possible both to evaluate the robustness of conclusions based on the WLP, and to study the effects of large owners' control and cash-flow rights empirically without having to rely on the existence of pyramids and different classes of share to obtain separate measures of such rights.

The paper proceeds as follows. Section 2 discusses how voting power indices can be used to measure the control rights of owners of firms. It also considers 
problems with the WLP as a measure of the control rights of ultimate owners (those at the top of a pyramid), and shows how voting power indices can be used to provide alternative measures of ultimate owners' control rights. Section 3 uses a sample of 97 large listed German firms to compare control rights measures based on voting power indices with those in which control rights are equated with voting rights, at both firsttier level (i.e., taking no account of pyramids) and ultimate ownership level. To evaluate which of these measures is most satisfactory, Section 4 compares their performance as explanatory variables in a regression model of the determinants of a firm's market-to-book ratio of equity value. Section 5 concludes.

\section{Measures of control rights}

\section{$\underline{2.1 \text { Voting power indices }}$}

There is an extensive literature on measures of the ability of a single voter to influence the outcome of a vote, and these voting power indices provide a natural way to derive a measure of the control rights of owners of a firm. Such indices have been used in some studies of corporate governance (Leech 1988, 2002, Pohjola 1988, Rydqvist 1986, Zingales 1994, Zwiebel 1995), but they have not become generally accepted as measures of control rights for reasons that are assessed below.

The two best known are the Shapley-Shubik and Banzhaf voting power indices (Shapley and Shubik 1954, Banzhaf 1965). These are illustrated in the following simple example. A company has three shareholders: shareholder 1 has 45 per cent of the votes, shareholder 2 has 35 per cent, and shareholder 3 has 20 per cent. Decisions are made by simple majority vote, so a proposal that receives at least 50 per cent of the votes will be enacted. What is the ability of each shareholder to influence the outcome of a vote?

The Shapley-Shubik voting power index answers this question by making a voter's power proportional to the number of times that voter is pivotal in a sequential coalition of voters, i.e., the number of times that voter changes a sequential coalition from a losing to a winning one by entering it. A sequential coalition is one formed by 
adding one voter at a time, with the order in which voters enter being important. In the example above, there are $6\left(=3\right.$ !) sequential coalitions containing all three players ${ }^{3}$, as follows: $\{1,2,3\},\{1,3,2\},\{2,1,3\},\{2,3,1\},\{3,1,2\},\{3,2,1\}$. The pivotal voter in each coalition is, respectively, 2, 3, 1, 3, 1, 2. The Shapley-Shubik index (SSI hereafter) for a particular voter is the number of times that voter is pivotal divided by the number of times all voters are pivotal. In this example, there are six sequential coalitions and hence six pivotal voters in total. Each individual voter is pivotal twice, so each voter has a SSI of 33.33 per cent. This example illustrates clearly voting power, as measured by the SSI, is not equal to voting rights.

The Banzhaf voting power index (BZI hereafter) measures a voter's ability to influence the outcome of a vote by making voting power proportional to the number of times that voter is a critical voter, i.e., the number of times that voter changes a winning coalition into a losing one by leaving it. A winning coalition is a coalition of voters that has enough votes to win. In the example, there are four winning coalitions: $\{1,2\},\{1,3\},\{2,3\}$ and $\{1,2,3\}$. The critical voters in each are, respectively, 1 and 2 , 1 and 3, 2 and 3, and none. The BZI for a particular voter is the number of times that voter is critical divided by the number of times all voters are critical. Each voter in the example thus has a BZI of 33.33 per cent, and voting power again differs from voting rights.

In this simple example, voting power is the same whether measured by the SSI or the BZI, but in general the two indices give different results. Suppose that a company has a single large shareholder, with 45 per cent of the votes, and 55 small shareholders each owning one per cent of the votes. In this case, the SSI for the large shareholder is 80.41 per cent, while each small shareholder has a SSI of 0.355 per cent. In contrast, the BZI for the large shareholder is 100 per cent, and each small shareholder has a BZI of zero. This second example not only illustrates that the SSI and BZI can give different results. Together with the first example, it also shows that the power of a given holding of voting rights (45 per cent in the two examples) depends greatly on the distribution of the other voting rights.

\footnotetext{
${ }^{3}$ With N players, there are $\mathrm{N}$ ! sequential coalitions
} 
The fact that the SSI and the BZI often give substantially different measures of the voting power associated with a given distribution of voting rights is one reason why these indices are not more widely used as measures of voting power. Another reason is that the theoretical foundations of the two indices are not clear-cut. ${ }^{4}$ In this paper, no attempt is made to resolve the question of which voting power index is theoretically preferable. Instead, the paper uses measures of control rights based on both the SSI and the BZI alongside a measure in which control rights are equated to voting rights, and compares the empirical performance of these three measures systematically.

One problem that typically arises when voting power indices are used to measure shareholder voting power is that not all shareholdings are observed, and hence assumptions must be made about the unobserved voting rights. The unobserved voting rights are usually those held by very small shareholders, so a natural assumption to make is that the total unobserved voting rights are dispersed over an infinitely large number of shareholders. This case is known as the oceanic one in the literature on voting power indices: there exists a large number (in the limit, an ocean) of 'minor' voters with positive total voting rights, but the voting rights of each individual minor voter tend to zero. The values given by the SSI are not very sensitive to the assumption made about unobserved voting rights, but this is not true for the BZI, and the SSI and BZI behave very differently in the oceanic case, as Dubey and Shapley (1979) show. If there is a single large shareholder holding a fraction $\mathrm{x}<0.5$ of the voting rights, the remaining fraction $1-\mathrm{x}$ is held by an ocean of small shareholders, and a simple majority is required to win a vote, then the SSI for the large shareholder is $\mathrm{x} / 1-\mathrm{x}$, while the BZI is always 100 per cent. ${ }^{5}$ Thus if a firm has a single large shareholder holding five per cent of the voting rights, and an ocean of small shareholders holding the remaining 95 per cent, the SSI for the large shareholder is 5.26 per cent but the BZI is 100 per cent. If the 95 per cent is held by 190 shareholders each with 0.5 per cent of the votes rather than by an ocean of small shareholders, the SSI for the large shareholder is 5.24 per cent, while the BZI is 5.91

\footnotetext{
${ }^{4}$ Felsenthal and Machover (1998) suggest that the two indices correspond to different conceptions of power.

${ }^{5}$ The general result is that the BZIs for the major voters in a situation with an ocean of minor voters are given by the BZIs for a different voting game, in which the only voters are the major voters and the fraction of votes required to win is equal to that in the original game less half the fraction of votes held by the ocean. See Dubey and Shapley (1979, pp. 110-118) for a full discussion.
} 
per cent. The value of the BZI is thus extremely sensitive to the assumption made about the unobserved voting rights, and the assumption that these are held by an ocean of small shareholders may not be appropriate when using the BZI. In the absence of a compelling alternative, however, the oceanic assumption is used in this paper.

\subsection{The weakest-link principle}

The WLP measures control rights in terms of actual voting rights: when control is exercised via a pyramid, it assigns control rights to the ultimate owner on the basis of the minimum value of actual voting rights across the different links of a control chain. Use of the WLP appears to originate with La Porta et al. (1999). It has also been used in the studies by Claessens et al. (2000), Claessens et al. (2002), Faccio and Lang (2002), and Faccio et al. (2001). La Porta et al. divide the firms in their sample into those that are widely held and those that have ultimate owners (several different types of which are identified). A firm has an ultimate owner if a controlling shareholder with more than some threshold value of voting rights (La Porta et al. use both 10 and 20 per cent as threshold values) can be identified using the WLP. A firm is widely held according to this approach if no ultimate owner can be identified using the WLP and the relevant threshold value of voting rights.

The absence of any theoretical foundation for the application of the WLP to the measurement of control rights in a control chain leads to a problem illustrated in the following example. Consider two control chains. In the first, ultimate owner 4 has 26 per cent of the voting rights in firm $\mathrm{C}$, which has 25 per cent of the voting rights in firm D. In the second, ultimate owner 5 has 90 per cent of the voting rights in firm E, which has 25 per cent of the voting rights in firm F. According to the WLP, the control rights of 4 in firm D and of 5 in firm $F$ are identical, at 25 per cent. Such a conclusion seems counter-intuitive, since although the two intermediate firms have identical voting rights in the firms at the bottom of the control chains, ultimate owner 5 has a far greater degree of control over firm $E$ than does ultimate owner 4 over firm $\mathrm{C}$, and it is difficult to accept that this difference should have no effect on the control rights of the two ultimate owners in the firms at the bottom of the control chains. One problem with the WLP is thus that ultimate owners with apparently very different 
degrees of control over firms at the bottom of control chains are sometimes measured as having similar, or identical, control rights.

It is possible for two or more ultimate owners to be identified by the WLP method employed by La Porta et al. When this happens, they "assign control to the shareholder with the largest ... voting stake". ${ }^{6}$ Their justification for ignoring the control rights of ultimate owners whose voting rights are not the largest single holding in a firm appears to be their finding that in 75 per cent of the cases they consider there is no large shareholder other than the one with the largest voting rights stake. ${ }^{7}$ This justification is not convincing: it means that, in one quarter of their cases, the implications of there being more than one ultimate owner with significant control rights (for example, possible limitations on the control rights of the largest owner because of monitoring by other large owners) are simply ignored. Faccio et al. (2001) use the WLP and a threshold value of 20 per cent for voting rights to identify the largest ultimate owner in firms in their sample. They find that 45.3 per cent of the European firms in their sample with such a controlling owner had another ultimate owner with at least 10 per cent of the voting rights. Among the Asian firms in their sample, 32.2 per cent of firms had another large ultimate owner as well as the largest was. It is clear that simply dismissing the existence of more than one ultimate owner with significant control rights is potentially very misleading. Faccio et al. use a multiple owners dummy variable to take account of such cases in some of their empirical analysis, but the widespread existence of firms with two or more large ultimate owners raises serious questions about the adequacy of the WLP as a basis for measuring the control rights of ultimate owners.

An example of the problems created by the absence of any well-specified theoretical basis for the WLP is provided by the case of Linotype-Hell, one of the German firms in our sample. Figure 1 illustrates the ownership of this firm. In 1991, the largest voting block (33.33 per cent) was held by Siemens AG (a corporation), while the second-largest holder of voting rights was the firm Frega, with 16.67 per cent. The remaining voting rights were dispersed. Of the voting rights in Siemens, 10 per cent were owned by the Siemens family, with the rest again being dispersed. Of

\footnotetext{
${ }^{6}$ La Porta et al. (1999), page 478, definition of widely-held.

${ }^{7}$ La Porta et al. (1999), page 505.
} 
the voting rights in Frega, 40 per cent were owned by Commerzbank, with three other owners each having 20 per cent. The largest first-tier holding of voting rights was that of Siemens AG, and, applying the WLP in its La Porta et al. version, this means that

Figure 1: Ownership of Linotype-Hell

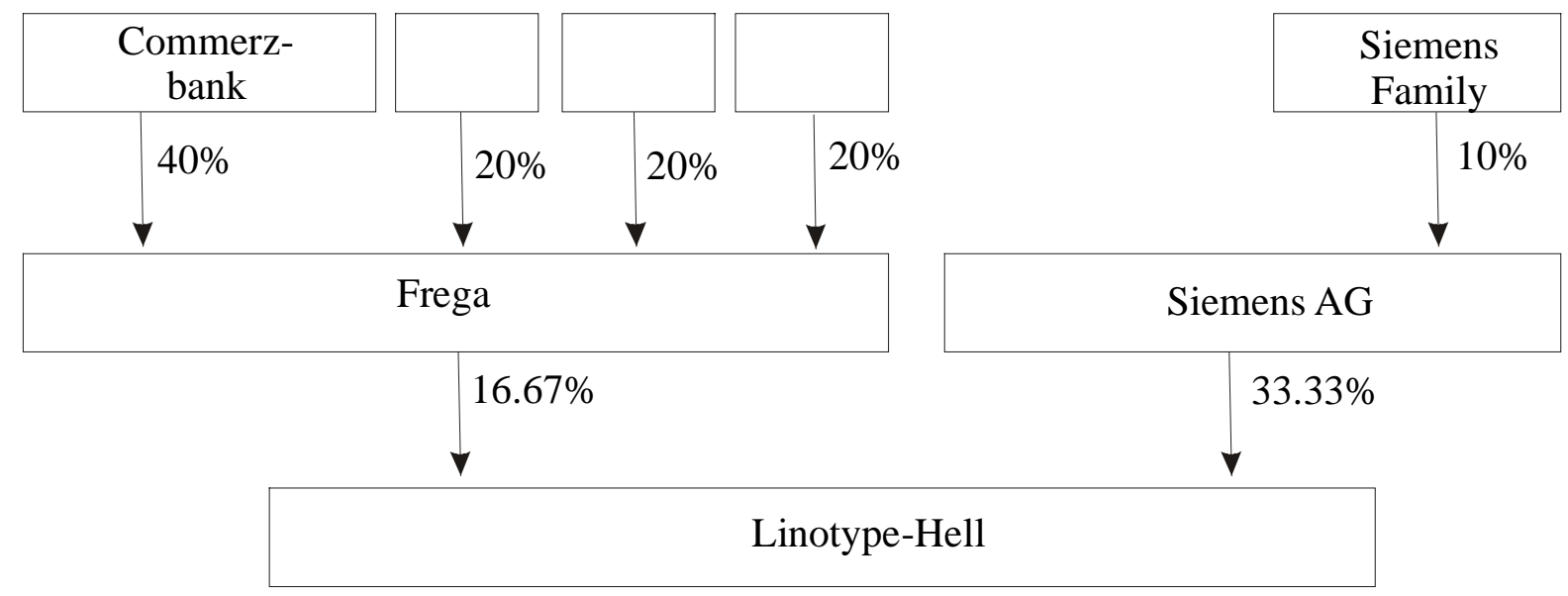

the ultimate owner of Linotype-Hell was the Siemens family, with control rights of 10 per cent. But it is far from obvious that this is an appropriate measure of the control rights of the largest owners of Linotype-Hell. If the WLP is applied to the control chain from Commerzbank to Linotype-Hell, Commerzbank would be assigned control rights of 16.67 per cent - a larger value than that of the Siemens family. Since Commerzbank may have had a less powerful position in Frega than the Siemens family had in Siemens AG (because three other owners each held 20 per cent of the voting rights in Frega), and Frega has fewer voting rights in Linotype-Hell than Siemens AG, it is not obvious whether Commerzbank has higher control rights in Linotype-Hell than the Siemens family. The point, however, is that the WLP cannot be applied in an obvious way to firms with multiple owners and multiple control chains.

An additional drawback of the WLP is that using a threshold value of voting rights to identify a controlling owner ignores the effect on the power of a given holding of voting rights of the distribution of the remaining voting rights across other owners, a point heavily emphasised in the literature on voting power indices. In their discussion of the WLP, La Porta et al. recognise that interactions between large 
owners are theoretically important for measures of ownership concentration, but they do not attempt to measure such concentration because they lack a satisfactory model of these interactions. ${ }^{8}$ Objections can certainly be raised to the theoretical models underlying the Shapley-Shubik and Banzhaf approaches to these interactions, but it is not clear that ignoring interactions altogether is a better approach. Faccio et al. use a multiple owners dummy variable to take some account of the existence of several large owners. However, their approach would, for example, treat an owner with 21 per cent of the voting rights in a firm in which the remaining voting rights were dispersed as having the same control rights as an owner with 21 per cent of the voting rights in a firm in which three other owners each held 9 per cent of the voting rights. Any approach to the measurement of control rights that uses thresholds in an attempt to bypass the question of interactions between owners is potentially misleading, because an owner's control rights are not uniquely determined by the value of her voting rights.

\section{$\underline{2.3 \text { Voting power indices, pyramids and control rights }}$}

Consider an example in which firm $\mathrm{M}$ has a single large owner, firm $\mathrm{N}$, which has 10 per cent of the voting rights, while the remaining 90 per cent are dispersed among an ocean of small shareholders. Suppose that firm $N$ is owned by three shareholders (1, 2 and 3) with voting rights of 45 per cent, 35 per cent and 20 per cent respectively. There is only one chain of control in this example, which leads to three ultimate owners. The smallest value in the chain of control is the 10 per cent ownership of firm M by firm N. The WLP as used by La Porta et al. would assign ultimate ownership of firm $M$ to shareholder 1, with control rights of 10 per cent, if a threshold value of 10 per cent were used, but would treat firm $\mathrm{M}$ as widely held if a threshold value of 20 per cent were used. Since La Porta et al. explicitly eschew the use of measures of ownership concentration and focus instead on identifying a single owner with effective control, they would assign the control rights in firm $\mathrm{N}$ to shareholder 1 and assign a value of zero to the control rights of shareholders 2 and 3 in firm N, and hence in firm M. This is not easily justifiable. The approach used by Faccio et al. would recognise the existence of multiple ultimate owners of firm $\mathrm{M}$

\footnotetext{
${ }^{8}$ La Porta et al. (1999), page 476.
} 
using a 10 per cent threshold value, but it is not clear what numerical values would be assigned to their control rights.

It is straightforward to apply voting power indices to the question of measuring the control rights of ultimate owners at the top of pyramid structures, as can be shown using the example just discussed. The SSI of firm N's voting power in firm $\mathrm{M}$ is 11.11 per cent. Each of the three owners of firm $\mathrm{N}$ has voting power of 33.33 per cent in it according to the SSI, and thus each ultimate owner of firm $\mathrm{M}$ has voting power of 3.7 per cent in $\mathrm{M}$ (3.7 per cent is 33.33 per cent of 11.11 per cent). According to the SSI, the remaining 88.89 per cent of the voting power in firm M belongs to the ocean of small shareholders, each of which has infinitesimally small voting rights. In contrast, the BZI of firm N's voting power in firm M is 100 per cent. Since each of the three owners of firm $\mathrm{N}$ has voting power of 33.33 per cent in it according to the BZI, each of firm M's ultimate owners has voting power of 33.33 per cent when the BZI is used.

It is instructive to apply the SSI and the BZI to the case of Linotype-Hell considered in Section 2.2. Assuming that the unobserved shareholdings are distributed among an ocean of small shareholders, Siemens AG has a SSI of 44.44 per cent in Linotype-Hell and Frega has a SSI of 11.12 per cent. The Siemens family has a SSI of 11.11 per cent in Siemens AG, and Commerzbank has a SSI of 50 per cent in Frega. Thus, according to the SSI, the control rights of the Siemens family in Linotype-Hell are 4.94 per cent, while those of Commerzbank are 5.56 per cent. In this case, the application of the SSI to the measurement of the control rights of ultimate owners is conceptually straightforward and produces intuitively plausible results, namely that it is hard to say which of Commerzbank and the Siemens family has the largest control rights in Linotype-Hell. According to the BZI, however, Siemens AG has 100 per cent of the voting power in Linotype-Hell, and the Siemens family has 100 per cent of the voting power in Siemens AG, so the Siemens family has all the control rights in Linotype-Hell and Commerzbank has none. Although it is straightforward to apply the BZI to Linotype-Hell, the results it produces are not intuitively plausible, because of the behaviour of the BZI in the oceanic case. 
The WLP lacks a theoretical foundation, and thus it is not clear how to apply it to control chains of any degree of complexity. In contrast, the SSI and the BZI can be applied to any control chains, however complex. The principles illustrated in the examples above carry over to the general case: to measure the control rights of ultimate owners in a control chain, the SSI and BZI are applied at all tiers in the control chain to obtain the voting power of the owners at each tier, and the control rights of the ultimate owners are obtained by working down the control chain from the top tier to the bottom one. In the next section, measures of control rights of ultimate owners obtained using the WLP, SSI and BZI are compared for a sample of German firms.

\section{Control rights measures for listed German firms}

The starting point for our sample of 97 listed German firms was the data on ownership at the end of 1991 collected by Nibler (1998) for 158 of the largest 200 non-financial German firms measured by turnover. Nibler's sample comprised all the firms in the largest 200 in 1991 that had not experienced significant changes in ownership over the period 1988-92. To arrive at our sample of 97, we excluded the unlisted firms from Nibler's sample. Our sample of 97 comprises all listed corporations from the largest 200 non-financial firms except 5, which were excluded because it was not possible to establish their ownership at the end of 1991 due to the existence of control contests. ${ }^{9}$ With a total of 563 listed German corporations in 1991, our sample accounts for a large proportion of the economic activity carried out by listed German firms. For these 97 firms we supplemented Nibler's data by collecting information concerning some balance-sheet ratios, the ratio of market value of equity to book value of equity, and ownership. For the latter, we used three sources Nibler's data, Wegweiser durch deutsche Unternehmen (published by Hypo-Bank), and Wer gehört zu Wem (published by Commerzbank) - to record all first-tier owners of firms with large enough holdings to be identified in these sources. When a first-tier owner was itself a closely-held firm, i.e., a firm with one or more identifiable large owners, we recorded the owners of that firm, and if any of these second-tier owners

\footnotetext{
${ }^{9}$ These five firms were Continental, Dyckerhoff \& Widmann, Th. Goldschmidt, Hoesch, and Philipp Holzmann. See Jenkinson and Ljungqvist (2001) for discussion of the problems involved in establishing the ownership of these firms, given the form that control contests take in Germany.
} 
were firms, we recorded their ownership, and so on until we established the ultimate owners. We classified ultimate owners into five different types: families (including foundations set up by families), widely-held domestic firms (both financial and nonfinancial), public-sector bodies, cooperatives, and foreign parent firms. A sixth ownership category was used for first-tier owners: closely-held firms. For each owner, the share of voting rights at the end of 1991 was measured, and used to establish both the largest and second-largest first-tier owners (i.e., taking no account of pyramid ownership structures), and the largest and second-largest ultimate owners (i.e., tracing ownership through pyramids where necessary). The measurement of voting rights took account of all relevant features, such as the existence of non-voting shares, multiple voting shares, and voting caps. Our recording of ownership structures also included information about multiple control chains and cross-holdings. ${ }^{10}$ In all but one case, multiple control chains and cross-holdings were incorporated into our measures of ultimate ownership straightforwardly. The exception is the insurance company Allianz, which is an important owner of firms in our sample, and which in 1991 owned the largest proportion of voting rights in both the largest and one of its joint second-largest holders of its voting rights (the insurance company Münchener Rückversicherung and Dresdner Bank respectively). Since Allianz appeared to control itself, it was classified as a widely-held firm. ${ }^{11}$

Panel A of Table 1 shows the control rights of the largest and second-largest first-tier owners measured in three different ways: by voting rights (suffix VR), by the SSI in the oceanic case (suffix SS), and by the BZI in the oceanic case (suffix BZ). The control rights of ultimate owners were also measured in three different ways: by the WLP (suffix WL), by the SSI in the oceanic case, and by the BZI in the oceanic case. Panel B shows the control rights of the largest ultimate owner, and, when the SSI and BZI were used, those of the second-largest ultimate owner. ${ }^{12}$

\footnotetext{
${ }^{10}$ Multiple control chains occur when there is more than one chain of voting rights from firms to their ultimate owners, while cross-holdings occur when a firm owns voting rights in a firm in its control chain.

${ }^{11}$ La Porta et al. (1999, p. 486) also classify Allianz as widely-held.

${ }^{12}$ As has been noted, the WLP offers no guidance on how to treat the control rights of owners other than the largest.
} 
Table 1: Measures of control rights of largest owners

\begin{tabular}{|c|c|c|c|c|c|c|}
\hline \multicolumn{7}{|c|}{ A: First-tier owners } \\
\hline Per cent & CR1VR & CR2VR & CR1SS & CR2SS & CR1BZ & CR2BZ \\
\hline 100 & 7 & 0 & 46 & 0 & 75 & 0 \\
\hline$>75-<100$ & 12 & 0 & 6 & 0 & 0 & 0 \\
\hline$>50-75$ & 26 & 0 & 4 & 0 & 1 & 0 \\
\hline$>25-50$ & 27 & 11 & 21 & 4 & 8 & 7 \\
\hline$>10-25$ & 13 & 20 & 9 & 15 & 2 & 6 \\
\hline$>0-10$ & 1 & 11 & 0 & 8 & 0 & 0 \\
\hline 0 & 11 & 55 & 11 & 70 & 11 & 84 \\
\hline Mean & 47.17 & $17.61^{\mathrm{a}}$ & 65.47 & $12.79^{\mathrm{a}}$ & 81.51 & $28.22^{\mathrm{a}}$ \\
\hline Median & 49 & $14.9^{\mathrm{a}}$ & 96.08 & $11.28^{\mathrm{a}}$ & 100 & $33.33^{\mathrm{a}}$ \\
\hline \multicolumn{7}{|c|}{ B: Ultimate owners } \\
\hline Per cent & UCR1WL & & UCR1SS & UCR2SS & UCR1BZ & UCR2BZ \\
\hline 100 & 7 & & 47 & 0 & 72 & 0 \\
\hline$>75-<100$ & 11 & & 5 & 0 & 1 & 0 \\
\hline$>50-75$ & 31 & & 5 & 0 & 3 & 0 \\
\hline$>25-50$ & 21 & & 16 & 4 & 8 & 7 \\
\hline$>10-25$ & 14 & & 11 & 11 & 2 & 6 \\
\hline$>0-10$ & 2 & & 2 & 12 & 0 & 0 \\
\hline 0 & 11 & & 11 & 70 & 11 & 84 \\
\hline Mean & 47.82 & & 64.14 & $12.77^{\mathrm{a}}$ & 80.74 & $28.02^{\mathrm{a}}$ \\
\hline Median & 50.1 & & 96.08 & $11.07^{\mathrm{a}}$ & 100 & $33.33^{\mathrm{a}}$ \\
\hline & & & & & & \\
\hline 2) & d & & & & & \\
\hline
\end{tabular}

A striking feature of Table 1 is the very small effect that tracing ownership through pyramids has on measures of owners' control rights, despite the fact that in 27 cases the largest first-tier owner was a closely-held firm and in 18 cases the secondlargest first-tier owner was a closely-held firm. Comparing the control rights figures for first-tier and ultimate owners given by each of the three measures shows that the mean, median and distribution of control rights for each measure are very similar. 
However, although tracing ownership through pyramids has small effects, the three different measures produce substantial differences in the control rights figures, as would be expected. Since both the SSI and BZI assign complete control to an owner with voting rights of $50 \%$ or more, but an owner has complete control according to the voting rights or WLP measures only with $100 \%$ of the voting rights, very many more owners have complete control according to the SSI and BZI measures. The number of ultimate owners with complete control is much greater if the BZI rather than the SSI is used, because of the behaviour of the BZI in the oceanic case. The number of first-tier second-largest owners with non-zero control rights is smaller when the SSI and BZI measures are used than when the voting rights measure is used. By its nature, the WLP does not identify any second-largest ultimate owners, but both the SSI and the BZI do (15 with control rights of more than 10 per cent according to the former, and 13 according to the latter). The distributions of control rights given in Table 1 show clearly that different measures yield substantially different views of the control rights of large owners, although the extent of these differences is hardly affected at all by whether first-tier or ultimate ownership is considered.

Although taking account of ownership exercised via pyramid structures has, for our sample of large German firms, very little effect on largest owners' control rights, the most important question is whether it increases the separation between the control and cash-flow rights of the largest owner. We measured the cash-flow rights of the largest first-tier owners as the fraction of total dividends paid in 1991 that such owners received, which we obtained using the proportions of voting and non-voting shares held by this owner, and the dividends paid to voting and non-voting shares. ${ }^{13}$ For the largest ultimate owners, cash-flow rights were measured by taking the product of the cash-flow rights at each ownership tier, measured by the fraction of total dividends received by the relevant owner at each tier. Table 2 shows the correlation coefficients between the control and cash-flow rights of the largest first-tier and largest ultimate owner, where, as usual, control rights are measured in three different ways. The identity of the largest first-tier owner was unaffected by the measure of control rights, and hence there is a single measure of the largest first-tier owner's cash-flow rights (CF1). In a small number of cases, the identity of the largest ultimate

\footnotetext{
${ }^{13}$ In Germany non-voting shares typically receive a slightly higher dividend than voting shares, and in 1991 payments to shareholders had to take the form of dividends.
} 
Table 2: Correlations between largest owner's control and cash-flow rights according to different measures

\begin{tabular}{|c|c|c|c|c|c|c|c|c|c|}
\hline & CR1SS & CR1BZ & CF1 & UCR1WL & UCR1SS & UCR1BZ & UCF1WL & UCF1SS & UCF1BZ \\
\hline CR1VR & 0.873 & 0.666 & 0.914 & 0.929 & 0.828 & 0.635 & 0.851 & 0.852 & 0.850 \\
\hline CR1SS & & 0.756 & 0.811 & 0.802 & 0.900 & 0.669 & 0.722 & 0.722 & 0.722 \\
\hline CR1BZ & & & 0.644 & 0.625 & 0.692 & 0.898 & 0.552 & 0.556 & 0.552 \\
\hline CF1 & & & & 0.831 & 0.754 & 0.598 & 0.897 & 0.898 & 0.896 \\
\hline UCR1WL & & & & 0.872 & 0.680 & 0.875 & 0.875 & 0.874 \\
\hline UCR1SS & & & & & & 0.735 & 0.804 & 0.802 & 0.805 \\
\hline UCR1BZ & & & & & & 0.592 & 0.596 & 0.594 \\
\hline UCF1WL & & & & & & & & 0.999 & 0.999 \\
\hline UCF1SS & & & & & & & & 0.999 \\
\hline
\end{tabular}

owner depended on whether control rights were measured according to the WLP, SSI or BZI, and thus there are three measures of the largest ultimate owner's cash-flow rights (UCF1 plus the appropriate suffix). Table 2 shows that taking account of pyramid structures results in a small increase in the separation between the largest owner's control and cash-flow rights for two of the three measures of control rights. The correlation between CR1VR and CF1 is 0.914 while that between UCR1WL and UCF1WL is 0.875 , and the correlation between CR1BZ and CF1 is 0.644 while that between UCR1BZ and UCF1BZ is 0.594. However, the correlation between CR1SS and CF1 is 0.811 while that between UCR1SS and UCF1SS is 0.802 . Overall, Table 2 shows that taking account of pyramid ownership structures results in only a very small increase in the separation of the largest owner's control and cash-flow rights, at least in terms of the correlation between them.

The evidence presented in this section shows that the three measures of control rights produce substantially different figures for the control rights of large owners in our sample of listed German firms. However, neither the figures for control rights nor the extent of the separation between the control and cash-flow rights of the largest owner appear to be much affected by whether ownership is traced back through pyramid structures or not. This raises the question of whether the emphasis placed on pyramids in studies of the effects of control and cash-flow rights is justified, an issue explored further in the next section. 


\section{Regression analysis of the effects of ownership structure on share valuation}

The two previous sections presented six different measures of largest owners' control and cash-flow rights - first-tier ones using voting rights, the SSI and the BZI, and ultimate ones using the WLP, the SSI and the BZI. In this section we attempt to establish whether one of these six measures can be regarded as superior to the others. Our earlier work (Edwards and Weichenrieder 2004) shows that the ratio of the market value of a firm's equity to its book value can be well explained by a regression model including both ownership and non-ownership variables. In that paper, the use of pyramid ownership structures as a means of separating control and cash-flow rights was not explicitly considered. Instead, control rights of first-tier owners were measured by the fraction of votes actually exercised by shareholders at the annual shareholder meeting, and cash-flow rights were measured taking account of the different dividend entitlements of voting and non-voting shares. The results showed that, for most types of largest shareholder, increases in control rights harm, and increases in cash-flow rights benefit, minority shareholders, with the net effect of equal increases in both being beneficial. In the present paper we evaluate the different measures of control rights discussed in previous sections by investigating how well they perform as ownership variables in this regression model.

The basic specification of the regression model used in Edwards and Weichenrieder (2004) is as follows:

$$
\begin{aligned}
& M T B=\text { Intercept }+\beta_{1} C R 1+\beta_{2} C F 1+\beta_{3} C R 2+\beta_{4} O T H+\beta_{5} P E N+\beta_{6} D E B T \\
& +\beta_{7} \text { SALESGR }+\beta_{8} \text { ASSETS }+\beta_{9} B E T A+(\text { Industrydummies })+\text { Errorterm }
\end{aligned}
$$

Here $M T B$ is the ratio of market to book value of equity capital, with market value measured on 31-12-1991 and book value being the 1991 figure. $C R 1$ and $C F 1$ are measures of the largest owner's control and cash-flow rights respectively, and $C R 2$ is a measure of the second-largest owner's control rights, all of these being the late 1991 figures. $O T H, P E N$ and $D E B T$ are the other provision, pension provision and debt ratios respectively, and ASSETS is total assets, all being the 1991 figures from the accounts. SALESGR is the proportional increase in firm sales between 1991 and 1990. BETA is a measure of idiosyncratic risk of each company. The reasons for including 
the non-ownership right-hand-side variables in the regression model are discussed in Edwards and Weichenrieder (2004): here we focus on the ownership variables.

A marginal shareholder in a firm will receive returns equal to his pro rata share of the firm's total profits less any private benefits of control appropriated by the dominant owner. ${ }^{14}$ If returns to a marginal shareholder are correctly anticipated, the price of the firm's shares will be given by the present value of these returns. If total profits are proportional to the book value of equity capital employed, the ratio of market to book value of equity capital will be lower the higher are the private benefits of control. Our basic hypotheses are first that, other things equal, the higher the largest owner's control rights, the higher the private benefits of control appropriated, and thus the lower is market value relative to book value. Second, we hypothesise that the higher this owner's cash-flow rights, the lower the private benefits of control appropriated, and thus the higher is market value relative to book value. Third, we hypothesise that, other things equal, the higher the control rights of the second-largest owner, the lower the private benefits appropriated (because the largest owner has to reckon with the presence of a second owner with non-trivial control rights), and thus the higher is market value relative to book value.

The firms in our sample have several different types of large owner. The behaviour of largest owners that are organisations run by agents may differ from that of largest owners that are families, since there is a much clearer relationship between the market value of equity and the wealth of the largest owner in the latter case. It is not obvious that, for such owners, greater control rights will lead to lower market-tobook ratios, and greater cash-flow rights to higher ones. To test whether the effects of largest owners' control and cash-flow rights differ by type of owner, we use interactive variables to identify the largest owner as either a family, a widely-held domestic firm, a public sector body, a cooperative sector body, or a foreign parent firm. When using first-tier ownership variables, we also include an interactive variable to identify largest first-tier owners that are closely-held firms.

\footnotetext{
${ }^{14}$ In principle minority holders of shares with voting rights could also expect some return because these voting rights had a significant probability of being pivotal in control contests. In practice, however, such gains to minority shareholders are virtually zero in Germany (Franks and Mayer, 2001).
} 


\subsection{Results using first-tier ownership measures}

Table 3 shows the results obtained when different versions of the regression model were estimated using first-tier ownership measures. All equations were estimated using OLS and the White heteroscedasticity-consistent estimator of the covariance matrix. ${ }^{15}$ The approach used was, for each measure of control rights (voting rights, SSI, BZI), first to estimate a general model (equations (3.1), (3.3) and (3.5) in Table 3), and then to impose acceptable restrictions on the general model to obtain a simpler model with better-determined coefficient estimates (equations (3.2), (3.4) and (3.6)).

There are some differences between the results obtained (after imposing restrictions) when control rights were measured respectively by voting rights and by the SSI, although these differences are not great. In equation (3.2), the estimated coefficient of the largest owner's control rights is negative and significant, and that of the largest owner's cash-flow rights is positive and significant, for all owner types. In equation (3.4), the estimated coefficient of the largest owner's control rights is negative for all owner types except the public sector, but the negative coefficient estimates are somewhat less well-determined than in equation (3.2), being significant only at the 0.10 level in two cases. The estimated coefficient of the largest owner's cash-flow rights is positive and significant for all owner types except the public sector, for which it is negative but insignificant. In (3.2) the estimated coefficient of the second-largest owner's control rights is positive and marginally significant (at the 0.061 level), but in (3.4) this coefficient, though positive, is not significant.

The results obtained when control rights were measured using the BZI are very different. The estimated coefficient of the largest owner's control rights in (3.6) is positive for some owner types and negative for others, and in only two cases is this coefficient significant (one being at the 0.10 level). A similar variation exists in the sign of the estimated coefficient of the largest owner's cash-flow rights, and only the estimate for family and foreign owner types is positive and significant. The estimated

\footnotetext{
${ }^{15}$ The justification for treating the ownership variables as exogenous is discussed in Section 4.3.
} 
Table 3: Regression results using first-tier ownership measures

\begin{tabular}{|c|c|c|c|c|c|c|}
\hline \multirow[b]{3}{*}{$\underline{\text { Regressors }}$} & \multicolumn{2}{|c|}{$\begin{array}{c}\text { Control rights measured by } \\
\text { voting rights }\end{array}$} & \multicolumn{2}{|c|}{$\begin{array}{c}\text { Control rights measured by } \\
\text { SSI }\end{array}$} & \multicolumn{2}{|c|}{$\begin{array}{c}\text { Control rights measured by } \\
\text { BZI }\end{array}$} \\
\hline & \multicolumn{2}{|c|}{ Equation Number } & \multicolumn{2}{|c|}{ Equation Number } & \multicolumn{2}{|c|}{ Equation Number } \\
\hline & 3.1 & 3.2 & 3.3 & 3.4 & 3.5 & 3.6 \\
\hline CR1(Family) & $\begin{array}{r}-1.90^{*} \\
(1.05)\end{array}$ & $\begin{array}{l}-2.01 * * \\
(0.83)\end{array}$ & $\begin{array}{l}-1.25^{*} \\
(0.68)\end{array}$ & $\begin{array}{l}-1.00 * \\
(0.53)\end{array}$ & $\begin{array}{l}-0.27 \\
(0.61)\end{array}$ & $\begin{array}{l}-0.32 \\
(0.50)\end{array}$ \\
\hline $\begin{array}{l}\text { CR1(Closely-held } \\
\text { firm) }\end{array}$ & $\begin{array}{l}-5.09 * * * \\
(1.54)\end{array}$ & $\begin{array}{l}-3.85 * * * \\
(1.07)\end{array}$ & $\begin{array}{l}-0.75 \\
(0.97)\end{array}$ & $\begin{array}{l}-1.69 * * * \\
(0.52)\end{array}$ & $\begin{array}{l}0.25 \\
(0.48)\end{array}$ & $\begin{array}{l}0.33 \\
(0.45)\end{array}$ \\
\hline $\begin{array}{l}\text { CR1(Widely-held } \\
\text { firm) }\end{array}$ & $\begin{array}{l}-16.47 \\
(18.64)\end{array}$ & $\begin{array}{l}-3.53 * * \\
(1.52)\end{array}$ & $\begin{array}{l}-3.65 \\
(2.45)\end{array}$ & $\begin{array}{l}-1.38 * * \\
(0.67)\end{array}$ & $\begin{array}{l}3.24 \\
(3.25)\end{array}$ & $\begin{array}{l}3.46^{* *} \\
(1.68)\end{array}$ \\
\hline CR1(Public) & $\begin{array}{l}-2.98 \\
(3.30)\end{array}$ & $\begin{array}{l}-5.56 * * * \\
(1.30)\end{array}$ & $\begin{array}{c}0.24 \\
(1.62)\end{array}$ & $\begin{array}{c}0.17 \\
(1.68)\end{array}$ & $\begin{array}{l}-0.14 \\
(0.95)\end{array}$ & $\begin{array}{l}-0.61 \\
(0.51)\end{array}$ \\
\hline CR1(Cooperative) & $\begin{array}{c}0.10 \\
(1.24)\end{array}$ & $\begin{array}{l}-4.23 * * * \\
(1.56)\end{array}$ & $\begin{array}{l}-1.71 \\
(4.73)\end{array}$ & $\begin{array}{l}-1.84 * * \\
(0.83)\end{array}$ & $\begin{array}{l}3.04 \\
(2.13)\end{array}$ & $\begin{array}{r}3.10^{*} \\
(1.81)\end{array}$ \\
\hline CR1(Foreign) & $\begin{array}{l}-2.61 \\
(1.79)\end{array}$ & $\begin{array}{l}-2.57 * * \\
(1.05)\end{array}$ & $\begin{array}{l}-1.99 \\
(1.23)\end{array}$ & $\begin{array}{l}-1.44 * \\
(0.67)\end{array}$ & $\begin{array}{l}-0.68 \\
(0.79)\end{array}$ & $\begin{array}{l}-0.62 \\
(0.59)\end{array}$ \\
\hline CF1(Family) & $\begin{array}{l}4.23 * * * \\
(1.38)\end{array}$ & & $\begin{array}{l}3.65^{* * *} \\
(1.15)\end{array}$ & & $\begin{array}{l}2.31 * * \\
(1.08)\end{array}$ & \\
\hline CF1(Closely-held & $5.69 * * *$ & & 1.70 & & 0.26 & 0.47 \\
\hline firm) & $(1.54)$ & & (1.64) & & $(0.95)$ & $(0.96)$ \\
\hline CF1(Widely-held & $\begin{array}{l}17.68 \\
(1972)\end{array}$ & & $\begin{array}{l}7.49 \\
(4.56)\end{array}$ & & -5.05 & -6.03 \\
\hline CF1(Public) & $\begin{array}{c}1.72 \\
(3.45)\end{array}$ & & $\begin{array}{l}-1.85 \\
(2.98)\end{array}$ & $\begin{array}{l}-1.64 \\
(3.08)\end{array}$ & $\begin{array}{l}-1.00 \\
(2.30)\end{array}$ & $\begin{array}{l}-1.02 \\
(2.32)\end{array}$ \\
\hline CF1(Cooperative) & - & & $\begin{array}{l}3.06 \\
(7.46)\end{array}$ & & $\begin{array}{l}-5.37 \\
(4.06)\end{array}$ & $\begin{array}{l}-4.79 \\
(4.11)\end{array}$ \\
\hline CF1(Foreign.) & $\begin{array}{l}4.42 * * \\
(2.21)\end{array}$ & & $\begin{array}{l}3.89 * * \\
(1.78)\end{array}$ & & $\begin{array}{l}2.50^{*} \\
(1.36)\end{array}$ & \\
\hline CF1(All) & & $\begin{array}{l}4.41 * * * \\
(1.02)\end{array}$ & & & & \\
\hline $\begin{array}{l}\text { CF1(All except } \\
\text { Public) }\end{array}$ & & & & $\begin{array}{l}3.35 * * * \\
(0.80)\end{array}$ & & \\
\hline $\begin{array}{l}\text { CF1(Family and } \\
\text { Foreign) } \\
\text { CF1(Closely-held } \\
\text { and Public) } \\
\text { CF1(Cooperative } \\
\text { and Widely-held) }\end{array}$ & & & & & & $\begin{array}{l}2.40 * * * \\
(0.83) \\
0.07 \\
(0.85) \\
-5.52 \\
(3.49)\end{array}$ \\
\hline CR2 & $\begin{array}{l}2.27 * \\
(1.21)\end{array}$ & $\begin{array}{l}2.11 * \\
(1.11)\end{array}$ & $\begin{array}{l}1.36 \\
(1.98)\end{array}$ & $\begin{array}{l}1.94 \\
(1.65)\end{array}$ & $\begin{array}{l}0.46 \\
(1.17)\end{array}$ & $\begin{array}{c}0.41 \\
(1.10)\end{array}$ \\
\hline $\begin{array}{l}\mathrm{R}^{2} \\
\text { Adjusted } \mathrm{R}^{2}\end{array}$ & $\begin{array}{l}0.6085 \\
0.4306\end{array}$ & 0.6044 & $\begin{array}{l}0.5987 \\
0.4073\end{array}$ & 0.5860 & $\begin{array}{l}0.5680 \\
0.3620\end{array}$ & 0.5662 \\
\hline
\end{tabular}

Notes: $* * *, * *, *$ indicate significance at the $0.01,0.05$, and 0.10 level respectively. Heteroscedasticityconsistent standard errors are in parentheses. All equations include a constant term and the other control variables specified in (1), the coefficients of which are not reported.

coefficient of the second-largest owner's control rights is positive but not significant. Using the BZI to measure control rights produces estimates of the effects of largest 
owners' control and cash-flow rights on the market-to-book ratio that differ greatly from those obtained using the other two measures both in sign and significance.

\section{$\underline{4.2 \text { Results using ultimate ownership measures }}$}

Table 4 shows the results obtained when the same approach was employed to estimate different versions of the regression model using ultimate ownership measures. When control rights were measured using the WLP, only the largest owner's control rights were included as regressors, for the reasons already noted.

In both equation (4.2) (in which control rights were measured using the WLP) and equation (4.4) (in which the SSI was used) the estimated coefficient of the control rights of largest owners that are public sector bodies is positive but not significant, while that for their cash-flow rights is negative and significant. For all other largest owners except widely-held domestic firms, the estimated control-rights coefficient is negative in both equations, although these coefficients are better determined in (4.4), and the estimated cash-flow-rights coefficient is positive in both equations. The control rights of second-largest owners do not appear in (4.2), while in (4.4) their estimated coefficient, though positive, is not significantly different from zero. The only difference between (4.2) and (4.4) concerns largest owners that are widely-held firms. In (4.2) the estimated coefficient of these owners' control rights is positive and significant, while the estimated coefficient of their cash-flow rights is negative (though insignificant) and significantly different from the estimated coefficient of all other largest owners' cash-flow rights except public sector bodies. However, in (4.4) the estimated coefficient of these owners' control rights is negative and significant, while that of their cash-flow rights is positive and not significantly different from that of all other largest owners' cash-flow rights except public sector bodies.

When ultimate ownership was measured using the BZI (equation (4.6)), the results are very different. The only estimated coefficient of largest owner control rights that is significant is for widely-held domestic firms, but it is positive. The sign of the estimated coefficient of the largest owner's cash-flow rights varies, and only the estimate for family and foreign owner types is positive and significant. As with 
Table 4: Regression results using ultimate ownership measures

\begin{tabular}{|c|c|c|c|c|c|c|}
\hline \multirow[b]{3}{*}{$\underline{\text { Regressors }}$} & \multicolumn{2}{|c|}{$\begin{array}{c}\text { Control rights measured by } \\
\text { WLP }\end{array}$} & \multicolumn{2}{|c|}{$\begin{array}{c}\text { Control rights measured by } \\
\text { SSI }\end{array}$} & \multicolumn{2}{|c|}{$\begin{array}{c}\text { Control rights measured by } \\
\text { BZI }\end{array}$} \\
\hline & \multicolumn{2}{|c|}{ Equation Number } & \multicolumn{2}{|c|}{ Equation Number } & \multicolumn{2}{|c|}{ Equation Number } \\
\hline & 4.1 & 4.2 & 4.3 & 4.4 & 4.5 & 4.6 \\
\hline CR1(Family) & $\begin{array}{l}-1.82 * \\
(1.03)\end{array}$ & $\begin{array}{l}-1.54^{*} \\
(0.88)\end{array}$ & $\begin{array}{l}-1.11 \\
(0.76)\end{array}$ & $\begin{array}{l}-1.38 * * \\
(0.56)\end{array}$ & $\begin{array}{l}-0.24 \\
(0.48)\end{array}$ & $\begin{array}{l}-0.28 \\
(0.40)\end{array}$ \\
\hline $\begin{array}{l}\text { CR1(Widely-held } \\
\text { firm) }\end{array}$ & $\begin{array}{l}3.03 * * \\
(1.31)\end{array}$ & $\begin{array}{l}2.72 * * \\
(1.18)\end{array}$ & $\begin{array}{l}-3.34 * \\
(1.70)\end{array}$ & $\begin{array}{l}-1.53 * * \\
(0.64)\end{array}$ & $\begin{array}{l}1.29 * * \\
(0.54)\end{array}$ & $\begin{array}{l}1.44 * * * \\
(0.48)\end{array}$ \\
\hline CR1(Public) & $\begin{array}{l}1.15 \\
(0.80)\end{array}$ & $\begin{array}{c}1.07 \\
(0.75)\end{array}$ & $\begin{array}{c}0.78 \\
(0.57)\end{array}$ & $\begin{array}{c}0.80 \\
(0.52)\end{array}$ & $\begin{array}{c}0.32 \\
(0.48)\end{array}$ & $\begin{array}{c}0.24 \\
(0.36)\end{array}$ \\
\hline CR1(Cooperative) & $\begin{array}{l}-1.57 \\
(1.83)\end{array}$ & $\begin{array}{l}-3.49 * * * \\
(1.19)\end{array}$ & $\begin{array}{l}-2.12 \\
(1.81)\end{array}$ & $\begin{array}{l}-3.05^{* * *} \\
(0.80)\end{array}$ & $\begin{array}{c}0.78 \\
(1.39)\end{array}$ & $\begin{array}{c}0.79 \\
(0.88)\end{array}$ \\
\hline CR1(Foreign) & $\begin{array}{l}-2.86 \\
(1.59)\end{array}$ & $\begin{array}{l}-2.17^{*} \\
(1.16)\end{array}$ & $\begin{array}{l}-2.56^{*} \\
(1.41)\end{array}$ & $\begin{array}{l}-2.13 * * * \\
(0.68)\end{array}$ & $\begin{array}{l}-0.78 \\
(0.84)\end{array}$ & $\begin{array}{l}-0.64 \\
(0.49)\end{array}$ \\
\hline CF1(Family) & $\begin{array}{l}4.04 * * * \\
(1.39)\end{array}$ & & $\begin{array}{l}3.21 * * \\
(1.30)\end{array}$ & & $\begin{array}{l}2.26 * * \\
(0.91)\end{array}$ & \\
\hline $\begin{array}{l}\text { CF1(Widely-held } \\
\text { firm) }\end{array}$ & $\begin{array}{l}-1.55 \\
(1.96)\end{array}$ & $\begin{array}{l}-1.31 \\
(1.86)\end{array}$ & $\begin{array}{l}7.41 * * \\
(3.43)\end{array}$ & & $\begin{array}{l}-0.89 \\
(1.63)\end{array}$ & \\
\hline CF1(Public) & $\begin{array}{l}-2.45^{* *} \\
(1.18)\end{array}$ & $\begin{array}{l}-2.42 * * \\
(1.16)\end{array}$ & $\begin{array}{l}-2.86 * * \\
(1.27)\end{array}$ & $\begin{array}{l}-2.97 * * \\
(1.19)\end{array}$ & $\begin{array}{l}-1.69 \\
(1.48)\end{array}$ & \\
\hline CF1(Cooperative) & $\begin{array}{l}1.50 \\
(1.67)\end{array}$ & & $\begin{array}{l}2.35 \\
(2.42)\end{array}$ & & $\begin{array}{l}-1.40 \\
(1.72)\end{array}$ & \\
\hline CF1(Foreign.) & $\begin{array}{l}4.37 * * \\
(2.01)\end{array}$ & & $\begin{array}{l}4.25^{* *} \\
(1.96)\end{array}$ & & $\begin{array}{r}2.52 * \\
(1.41)\end{array}$ & \\
\hline $\begin{array}{l}\text { CF1(All except } \\
\text { Public and } \\
\text { Widely-held) }\end{array}$ & & $\begin{array}{l}3.59 * * * \\
(1.11)\end{array}$ & & & & \\
\hline $\begin{array}{l}\text { CF1(All except } \\
\text { Public) }\end{array}$ & & & & $\begin{array}{l}3.66 * * * \\
(0.86)\end{array}$ & & \\
\hline $\begin{array}{l}\text { CF1(Family and } \\
\text { Foreign) } \\
\text { CF1(Public, Coop } \\
\text { and Widely-held) }\end{array}$ & & & & & & $\begin{array}{l}2.35 * * * \\
(0.71) \\
-1.41 \\
(0.92)\end{array}$ \\
\hline CR2 & & & $\begin{array}{l}0.30 \\
(1.02)\end{array}$ & $\begin{array}{l}1.09 \\
(0.89)\end{array}$ & $\begin{array}{l}-0.15 \\
(0.82)\end{array}$ & $\begin{array}{l}-0.14 \\
(0.73)\end{array}$ \\
\hline $\begin{array}{l}\mathrm{R}^{2} \\
\text { Adjusted } \mathrm{R}^{2}\end{array}$ & $\begin{array}{l}0.5915 \\
0.4233\end{array}$ & $\begin{array}{l}0.5870 \\
0.4335\end{array}$ & $\begin{array}{l}0.6114 \\
0.4432\end{array}$ & 0.6033 & $\begin{array}{l}0.5777 \\
0.3949\end{array}$ & 0.5768 \\
\hline
\end{tabular}

Notes: ***, **,* indicate significance at the $0.01,0.05$, and 0.10 level respectively. Heteroscedasticityconsistent standard errors are in parentheses. All equations include a constant term and the other control variables specified in (1), the coefficients of which are not reported.

first-tier ownership, the estimates of the effects of largest owners' control and cashflow rights on the market-to-book ratio obtained when the BZI was used to measure control rights of ultimate owners differ greatly in sign and significance from those obtained using the other two measures. 


\section{$\underline{4.3 \text { Testing the assumption of exogenous ownership }}$}

The regression equations reported in Tables 3 and 4 were all estimated by OLS, which will not yield consistent estimates if the ownership variables are endogenous. To test whether our assumption that the ownership variables are exogenous was justifiable, we estimated a slightly modified version of the restricted models in Tables 3 and 4 by instrumental variables (IV). The instruments for the ownership variables were as follows. First, turnover, an alternative measure of firm size to that included as an explanatory variable, since an inverse relationship between size and ownership concentration would be expected. Second, age, on the grounds that the older a firm is, the less likely is it to have concentrated ownership because of the holdings of its founders. Third, the risk measure (BETA) included as an explanatory variable in all equations reported in Tables 3 and 4, but which was always insignificant. The higher a firm's specific risk, the lower its ownership concentration is likely to be, for diversification reasons. Fourth, a dummy variable showing which of the firms in our sample had the same largest shareholder in 1979 as in 1991 (57 of them did so). The final instruments were dummy variables indicating the type of largest owner (family, public sector, etc.). In the first-stage regressions of the ownership variables on these instruments the null hypothesis that the estimated coefficients of all the instruments were zero was always strongly rejected, so these instruments are reasonably well correlated with the ownership variables. Hausman tests of the significance of the differences between the OLS and IV coefficient estimates of the restricted equations in Tables 3 and 4 (excluding BETA) did not reject the null hypothesis of no difference. ${ }^{16}$ Given the instruments available, there is no evidence that the results reported in Tables 3 and 4 are dependent on the inappropriate use of OLS as an estimation method.

These regression results show that there is a stronger relationship between the market-to-book ratio and largest owners' control and cash-flow rights when control rights are measured using either voting rights and the WLP or the SSI than when they are measured using the BZI. The BZI is thus an unsatisfactory measure of control

\footnotetext{
${ }^{16}$ Under the null hypothesis of exogenous ownership variables, both OLS and IV are consistent but IV is inefficient, whereas under the alternative IV is consistent but OLS is not. Hence, under the null hypothesis, the two sets of coefficient estimates should not differ significantly.
} 
rights. However, in terms of the estimates of the regression model, it is clear neither whether voting rights and the WLP are a better measure of control rights than the SSI nor whether first-tier ownership measures are superior to ultimate ownership measures. To investigate this further, we use non-nested tests of the various regression models in Tables 3 and 4.

\section{$\underline{4.4 \text { Non-nested testing of ownership measures }}$}

The problem we face, conditional on equation (1) being the appropriate regression model, is that of determining which of several possible sets of ownership variables is the appropriate set of regressors. This is a standard problem of choice among non-nested models, and we tested each of the models given by equations (3.1), (3.3), (3.5), (4.1), (4.3) and (4.5) against the five others using a $\mathrm{J}$ test. ${ }^{17}$ The results are summarised in Table 5. Focussing initially on the tests of the three ultimate ownership models against each other, the model in which ownership is measured by the SSI (4.3) is only rejected at the 0.10 level by the models in which ownership is measured by the WLP (4.1) and the BZI (4.5). Both the other ultimate ownership models are rejected at the 0.01 level by the ultimate SSI model. This suggests that the ultimate ownership model in which control rights are measured by the SSI is superior to the other two ultimate ownership models. However, although this model is neither rejected by the model in which first-tier ownership is measured using the SSI (3.3) nor by that in which it is measured using the BZI (3.5), it is rejected at the 0.01 level by the model in which first-tier ownership is measured using voting rights (3.1). Model (3.1), however, is rejected at the 0.01 level by all three ultimate ownership models. Thus, as is possible in non-nested hypothesis testing, the results in Table 5 show that none of the models tested are fully adequate: all models are rejected at the 0.01 level by at least one other model.

The results of the non-nested tests do not permit unambiguous answers to the questions of whether first-tier ownership measures are superior to ultimate ones, and whether voting rights and the WLP are better measures of control rights than the

\footnotetext{
${ }^{17}$ Davidson and MacKinnon (1981).
} 
Table 5: Results of non-nested tests

\begin{tabular}{|c|c|c|c|c|c|c|c|c|}
\hline & & & \multicolumn{3}{|c|}{ First-tier ownership } & \multicolumn{3}{|c|}{ Ultimate ownership } \\
\hline & & & VR & SS & $\mathrm{BZ}$ & WL & SS & $\mathrm{BZ}$ \\
\hline & & Model & $(3.1)$ & (3.3) & $(3.5)$ & $(4.1)$ & $(4.3)$ & $(4.5)$ \\
\hline \multirow{3}{*}{$\begin{array}{l}\text { First-tier } \\
\text { ownership }\end{array}$} & VR & $(3.1)$ & - & $\mathrm{R}^{* *}$ & $\mathrm{R}^{*}$ & $\mathrm{R}^{* * *}$ & $\mathrm{R}^{* * *}$ & $\mathrm{R}^{* * *}$ \\
\hline & $\mathrm{SS}$ & (3.3) & $\mathrm{R} * * *$ & - & NR & $\mathrm{R}^{* *}$ & $\mathrm{R}^{* * *}$ & $\mathrm{R}^{* *}$ \\
\hline & BZ & $(3.5)$ & $\mathrm{R} * * *$ & $\mathrm{R}^{* * *}$ & - & $\mathrm{R}^{* * *}$ & $\mathrm{R}^{* * *}$ & $\mathrm{R}^{* *}$ \\
\hline \multirow{3}{*}{$\begin{array}{l}\text { Ultimate } \\
\text { ownership }\end{array}$} & WL & $(4.1)$ & $\mathrm{R} * * *$ & $\mathrm{R}^{* * *}$ & $\mathrm{R}^{*}$ & - & $\mathrm{R}^{* * *}$ & $\mathrm{R}^{*}$ \\
\hline & $\mathrm{SS}$ & $(4.3)$ & $\mathrm{R} * * *$ & NR & NR & $\mathrm{R}^{*}$ & - & $\mathrm{R}^{*}$ \\
\hline & $\mathrm{BZ}$ & $(4.5)$ & $\mathrm{R} * * *$ & $\mathrm{R}^{* * *}$ & NR & $\mathrm{R}^{* *}$ & $\mathrm{R} * * *$ & - \\
\hline
\end{tabular}

Notes: Each cell shows the result of testing the row model against the column model by a J test. R indicates that the row model was rejected by the column model, and NR indicates that the row model was not rejected by the column model. ***, **, * indicate significance at the $0.01,0.05$, and 0.10 level respectively.

SSI. If, in order to assess the effects of the largest owner's control and cash-flow rights on minority shareholders, the maintained hypothesis is that ownership must be traced through pyramid structures, then our results suggest that the SSI is superior to the WLP. But our results do not support the maintained hypothesis that ownership is better measured at the ultimate than at the first-tier level. First-tier ownership measures add something to the explanation of the market-to-book ratio given by ultimate ones (in the case of the ultimate SSI model admittedly only the first-tier voting rights model does this), just as ultimate measures add something to the explanation given by first-tier ones. This means that the ultimate SSI model can, at best, be described as the model that suffers the smallest number of rejections by other models.

The inability to identify an unambiguously best regression model means that some aspects of the conflict of interest between controlling and minority shareholders in large German firms remain unclear. Irrespective of how ownership is measured - at first-tier or ultimate levels, by voting rights and the WLP or the SSI - increases in the control rights of most types of largest owner reduce the market-to-book ratio, implying that minority shareholders are harmed by such increases, while increases in the cash-flow rights of most largest owners raise the market-to-book ratio, implying 
that minority shareholders benefit from such increases. However, the different models do not give a completely consistent picture. For example, increases in the control rights of largest owners that are widely-held domestic firms are estimated to have a significant positive effect on the market-to-book ratio if ownership is measured at the ultimate level using the WLP, but if ownership is measured at the ultimate level using the SSI, or at the first-tier level using either voting rights or the SSI, increases in these owners' control rights are estimated to have a significant negative effect. It is also not clear whether minority shareholders benefit from increases in the control rights of the second-largest owner: this effect is positive and marginally significant according to the first-tier model using voting rights, but it is not significant (though positive) according to the ultimate SSI model.

\section{Conclusion}

This paper raises several questions about the recent empirical literature on the conflict of interest between large and minority shareholders, in which measures of the control and cash-flow rights of large shareholders play a critical role. In measuring the largest owner's control and cash-flow rights, this literature has placed great emphasis on the need to trace ownership through pyramid structures, and has used the WLP to provide measures of the control rights of ultimate owners. We argue that there are a number of problems with the use of the WLP, and propose an alternative approach to the measurement of control rights based on the use of voting power indices. Such an approach provides a more theoretically satisfactory method of calculating control rights measures for ultimate owners. It also enables separate measures of control and cash-flow rights to be obtained even in the absence of pyramids and dual-class shares.

Our results for a sample of large listed German firms show that, whatever the measure used, the differences between control and cash-flow rights measured at the first-tier and the ultimate levels are very small. Our results also show that neither firsttier nor ultimate ownership measures are adequate on their own, which suggests that further work on the determinants of ownership structure and the role of pyramids is required in order to obtain fully satisfactory measures of large owners' control and cash-flow rights. It is likely that the existence of pyramid ownership structures cannot be explained solely in terms of controlling owners' desire to separate cash-flow and 
control rights. A possible additional reason for pyramid structures is that ownership of a firm through an intermediate pyramid firm acts as a commitment device for the several owners of the firm to exercise their control rights in the same way.

If, however, the maintained hypothesis that ownership should be measured at the ultimate level is adopted, as is the case in most of the recent empirical literature, our results suggest that the WLP measure of control rights is inferior to the SSI one. This implies that the results of the existing literature, which has focussed almost exclusively on ultimate ownership using the WLP measure of control rights, must be regarded as provisional. Although our results show that some conclusions about the effects of large owners' control and cash-flow rights on minority shareholders are robust to the particular measures used, others are not.

\section{References}

Banzhaf, J.F. (1965), 'Weighted voting doesn't work: a mathematical analysis', Rutgers Law Review 19, 317-343.

Barclay, M. J. and C. G. Holderness (1989), 'Private benefits from control of public corporations', Journal of Financial Economics 25, 371-395.

Bergström, C. and K. Rydqvist (1990), 'Ownership of equity in dual-class firms', Journal of Banking and Finance 14, 255-269.

Claessens, S., S. Djankov, and L.H.P. Lang (2000), 'The separation of ownership and control in East Asian corporations', Journal of Financial Economics 58, 81112.

Claessens, S., S. Djankov, J.P.H. Fan, and L.H.P. Lang (2002), 'Disentangling the incentive and entrenchment effects of large shareholdings', Journal of Finance $57,2741-2771$.

Davidson, R. and J. MacKinnon (1981), 'Several tests for model specification in the presence of alternative hypotheses', Econometrica 49, 781-793. 
Dubey, P. and L.S. Shapley (1979), 'Mathematical properties of the Banzhaf power index', Mathematics of Operations Research 4, 99-131.

Dyck, A. and L. Zingales (2004), 'Private benefits of control: an international comparison', Journal of Finance 59, 537-600.

Edwards, J.S.S. and A.J. Weichenrieder (2004), 'Ownership concentration and share valuation', German Economic Review 5, 143-171.

Faccio, M. and L.H.P. Lang (2002), 'The ultimate ownership of Western European corporations', Journal of Financial Economics 65, 365-395.

Faccio, M., L.H.P. Lang and L. Young (2001), 'Dividends and expropriation', American Economic Review, 91, 54-78.

Felsenthal, D.S. and M. Machover (1998), The Measurement of Voting Power, Cheltenham: Edward Elgar.

Franks, J. R. and C. P. Mayer (2001), 'The ownership and control of German corporations', Review of Financial Studies, 14, 943-977.

Jenkinson, T. and A. Ljungqvist (2001), 'The role of hostile stakes in German corporate governance', Journal of Corporate Finance, 7, 397-446.

Jensen M. C. and W. H. Meckling (1976), 'Theory of the firm: managerial behavior, agency costs and ownership structure', Journal of Financial Economics 3, 305-360.

Johnson, S., R. La Porta, F. Lopez-de-Silanes and A. Shleifer (2000), 'Tunneling', American Economic Review, 90, 22-27.

La Porta, R., F. Lopez-de-Silanes and A. Shleifer (1999), 'Corporate ownership around the world', Journal of Finance 54, 471-517. 
Leech, D. (1988), 'The relationship between shareholding concentration and shareholder voting power in British companies: a study of the application of power indices for simple games', Management Science 34, 509-527.

Leech, D. (2002), 'An empirical comparison of the performance of classical power indices', Political Studies 50, 1-22.

Nenova, T. (2003), 'The value of corporate voting rights and control: a cross-country analysis', Journal of Financial Economics 68, 325-351.

Nibler, M. F. (1998), Bank Control and Corporate Performance in Germany: The Evidence, unpublished $\mathrm{PhD}$ Thesis, University of Cambridge.

Pohjola, M. (1988), 'Concentration of shareholder voting power in Finnish industrial companies', Scandinavian Journal of Economics 90, 245-253.

Rydqvist, K. (1986), The Pricing of Shares with Different Voting Power and the Theory of Oceanic Games, Stockholm: Economic Research Institute, Stockholm School of Economics.

Shapley, L.S., and M. Shubik (1954), 'A method for evaluating the distribution of power in a committee system', American Political Science Review 48, 787792.

Shleifer, A. and R. W. Vishny (1997), 'A survey of corporate governance', Journal of Finance 52, 737-783.

Zingales, L. (1994), 'The value of the voting right: A study of the Milan stock exchange experience', Review of Financial Studies 7, 125-148.

Zwiebel, J. (1995), 'Block investment and partial benefits of corporate control', Review of Economic Studies 62, 161-185. 


\section{CESifo Working Paper Series}

(for full list see www.cesifo.de)

1193 Inés Macho-Stadler and David Pérez-Castrillo, Optimal Enforcement Policy and Firms' Emissions and Compliance with Environmental Taxes, May 2004

1194 Paul De Grauwe and Marianna Grimaldi, Bubbles and Crashes in a Behavioural Finance Model, May 2004

1195 Michel Berne and Gérard Pogorel, Privatization Experiences in France, May 2004

1196 Andrea Galeotti and José Luis Moraga-González, A Model of Strategic Targeted Advertising, May 2004

1197 Hans Gersbach and Hans Haller, When Inefficiency Begets Efficiency, May 2004

1198 Saku Aura, Estate and Capital Gains Taxation: Efficiency and Political Economy Consideration, May 2004

1199 Sandra Waller and Jakob de Haan, Credibility and Transparency of Central Banks: New Results Based on Ifo's World Economicy Survey, May 2004

1200 Henk C. Kranendonk, Jan Bonenkamp, and Johan P. Verbruggen, A Leading Indicator for the Dutch Economy - Methodological and Empirical Revision of the CPB System, May 2004

1201 Michael Ehrmann, Firm Size and Monetary Policy Transmission - Evidence from German Business Survey Data, May 2004

1202 Thomas A. Knetsch, Evaluating the German Inventory Cycle - Using Data from the Ifo Business Survey, May 2004

1203 Stefan Mittnik and Peter Zadrozny, Forecasting Quarterly German GDP at Monthly Intervals Using Monthly IFO Business Conditions Data, May 2004

1204 Elmer Sterken, The Role of the IFO Business Climate Indicator and Asset Prices in German Monetary Policy, May 2004

1205 Jan Jacobs and Jan-Egbert Sturm, Do Ifo Indicators Help Explain Revisions in German Industrial Production?, May 2004

1206 Ulrich Woitek, Real Wages and Business Cycle Asymmetries, May 2004

1207 Burkhard Heer and Alfred Maußner, Computation of Business Cycle Models: A Comparison of Numerical Methods, June 2004 
1208 Costas Hadjiyiannis, Panos Hatzipanayotou, and Michael S. Michael, Pollution and Capital Tax Competition within a Regional Block, June 2004

1209 Stephan Klasen and Thorsten Nestmann, Population, Population Density, and Technological Change, June 2004

1210 Wolfgang Ochel, Welfare Time Limits in the United States - Experiences with a New Welfare-to-Work Approach, June 2004

1211 Luis H. R. Alvarez and Erkki Koskela, Taxation and Rotation Age under Stochastic Forest Stand Value, June 2004

1212 Bernard M. S. van Praag, The Connexion Between Old and New Approaches to Financial Satisfaction, June 2004

1213 Hendrik Hakenes and Martin Peitz, Selling Reputation When Going out of Business, June 2004

1214 Heikki Oksanen, Public Pensions in the National Accounts and Public Finance Targets, June 2004

1215 Ernst Fehr, Alexander Klein, and Klaus M. Schmidt, Contracts, Fairness, and Incentives, June 2004

1216 Amihai Glazer, Vesa Kanniainen, and Panu Poutvaara, Initial Luck, Status-Seeking and Snowballs Lead to Corporate Success and Failure, June 2004

1217 Bum J. Kim and Harris Schlesinger, Adverse Selection in an Insurance Market with Government-Guaranteed Subsistence Levels, June 2004

1218 Armin Falk, Charitable Giving as a Gift Exchange - Evidence from a Field Experiment, June 2004

1219 Rainer Niemann, Asymmetric Taxation and Cross-Border Investment Decisions, June 2004

1220 Christian Holzner, Volker Meier, and Martin Werding, Time Limits on Welfare Use under Involuntary Unemployment, June 2004

1221 Michiel Evers, Ruud A. de Mooij, and Herman R. J. Vollebergh, Tax Competition under Minimum Rates: The Case of European Diesel Excises, June 2004

1222 S. Brock Blomberg and Gregory D. Hess, How Much Does Violence Tax Trade?, June 2004

1223 Josse Delfgaauw and Robert Dur, Incentives and Workers' Motivation in the Public Sector, June 2004

1224 Paul De Grauwe and Cláudia Costa Storti, The Effects of Monetary Policy: A MetaAnalysis, June 2004 
1225 Volker Grossmann, How to Promote R\&D-based Growth? Public Education Expenditure on Scientists and Engineers versus R\&D Subsidies, June 2004

1226 Bart Cockx and Jean Ries, The Exhaustion of Unemployment Benefits in Belgium. Does it Enhance the Probability of Employment?, June 2004

1227 Bertil Holmlund, Sickness Absence and Search Unemployment, June 2004

1228 Klaas J. Beniers and Robert Dur, Politicians' Motivation, Political Culture, and Electoral Competition, June 2004

1229 M. Hashem Pesaran, General Diagnostic Tests for Cross Section Dependence in Panels, July 2004

1230 Wladimir Raymond, Pierre Mohnen, Franz Palm, and Sybrand Schim van der Loeff, An Empirically-Based Taxonomy of Dutch Manufacturing: Innovation Policy Implications, July 2004

1231 Stefan Homburg, A New Approach to Optimal Commodity Taxation, July 2004

1232 Lorenzo Cappellari and Stephen P. Jenkins, Modelling Low Pay Transition Probabilities, Accounting for Panel Attrition, Non-Response, and Initial Conditions, July 2004

1233 Cheng Hsiao and M. Hashem Pesaran, Random Coefficient Panel Data Models, July 2004

1234 Frederick van der Ploeg, The Welfare State, Redistribution and the Economy, Reciprocal Altruism, Consumer Rivalry and Second Best, July 2004

1235 Thomas Fuchs and Ludger Woessmann, What Accounts for International Differences in Student Performance? A Re-Examination Using PISA Data, July 2004

1236 Pascalis Raimondos-Møller and Alan D. Woodland, Measuring Tax Efficiency: A Tax Optimality Index, July 2004

1237 M. Hashem Pesaran, Davide Pettenuzzo, and Allan Timmermann, Forecasting Time Series Subject to Multiple Structural Breaks, July 2004

1238 Panu Poutvaara and Andreas Wagener, The Invisible Hand Plays Dice: Eventualities in Religious Markets, July 2004

1239 Eckhard Janeba, Moral Federalism, July 2004

1240 Robert S. Chirinko, Steven M. Fazzari, and Andrew P. Meyer, That Elusive Elasticity: A Long-Panel Approach to Estimating the Capital-Labor Substitution Elasticity, July 2004

1241 Hans Jarle Kind, Karen Helene Midelfart, Guttorm Schjelderup, Corporate Tax Systems, Multinational Enterprises, and Economic Integration, July 2004 
1242 Vankatesh Bala and Ngo Van Long, International Trade and Cultural Diversity: A Model of Preference Selection, July 2004

1243 Wolfgang Eggert and Alfons J. Weichenrieder, On the Economics of Bottle Deposits, July 2004

1244 Sören Blomquist and Vidar Christiansen, Taxation and Heterogeneous Preferences, July 2004

1245 Rafael Lalive and Alois Stutzer, Approval of Equal Rights and Gender Differences in Well-Being, July 2004

1246 Paolo M. Panteghini, Wide vs. Narrow Tax Bases under Optimal Investment Timing, July 2004

1247 Marika Karanassou, Hector Sala, and Dennis J. Snower, Unemployment in the European Union: Institutions, Prices, and Growth, July 2004

1248 Engin Dalgic and Ngo Van Long, Corrupt Local Government as Resource Farmers: The Helping Hand and the Grabbing Hand, July 2004

1249 Francesco Giavazzi and Guido Tabellini, Economic and Political Liberalizations, July 2004

1250 Yin-Wong Cheung and Jude Yuen, An Output Perspective on a Northeast Asia Currency Union, August 2004

1251 Ralf Elsas, Frank Heinemann, and Marcel Tyrell, Multiple but Asymmetric Bank Financing: The Case of Relationship Lending, August 2004

1252 Steinar Holden, Wage Formation under Low Inflation, August 2004

1253 Ngo Van Long and Gerhard Sorger, Insecure Property Rights and Growth: The Roles of Appropriation Costs, Wealth Effects, and Heterogeneity, August 2004

1254 Klaus Wälde and Pia Weiß, International Competition, Slim Firms and Wage Inequality, August 2004

1255 Jeremy S. S. Edwards and Alfons J. Weichenrieder, How Weak is the Weakest-Link Principle? On the Measurement of Firm Owners' Control Rights, August 2004 